\title{
A European interlaboratory trial to evaluate the performance of different PCR methods for Mycoplasma bovis diagnosis
}

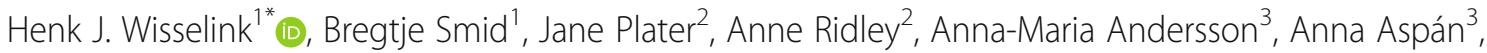
Tarja Pohjanvirta ${ }^{4}$, Nella Vähänikkilä ${ }^{4}$, Helene Larsen ${ }^{5}$, Jonas Høgberg ${ }^{5}$, Adélie Colin ${ }^{6}$ and Florence Tardy ${ }^{6}$

\begin{abstract}
Background: Several species-specific PCR assays, based on a variety of target genes are currently used in the diagnosis of Mycoplasma bovis infections in cattle herds with respiratory diseases and/or mastitis. With this diversity of methods, and the development of new methods and formats, regular performance comparisons are required to ascertain diagnostic quality. The present study compares PCR methods that are currently used in six national veterinary institutes across Europe. Three different sample panels were compiled and analysed to assess the analytical specificity, analytical sensitivity and comparability of the different PCR methods. The results were also compared, when appropriate, to those obtained through isolation by culture. The sensitivity and comparability panels were composed of samples from bronchoalveolar fluids of veal calves, artificially contaminated or naturally infected, and hence the comparison of the different methods included the whole workflow from DNA extraction to PCR analysis.
\end{abstract}

Results: The participating laboratories used i) five different DNA extraction methods, ii) seven different real-time and/or end-point PCRs targeting four different genes and iii) six different real-time PCR platforms. Only one commercial kit was assessed; all other PCR assays were in-house tests adapted from published methods. The analytical specificity of the different PCR methods was comparable except for one laboratory where Mycoplasma agalactiae was tested positive. Frequently, weak-positive results with Ct values between 37 and 40 were obtained for non-target Mycoplasma strains. The limit of detection (LOD) varied from 10 to $10^{3} \mathrm{CFU} / \mathrm{ml}$ to $10^{3}$ and $10^{6} \mathrm{CFU}$ / $\mathrm{ml}$ for the real-time and end-point assays, respectively. Cultures were also shown to detect concentrations down to $10^{2} \mathrm{CFU} / \mathrm{ml}$. Although Ct values showed considerable variation with naturally infected samples, both between laboratories and tests, the final result interpretation of the samples (positive versus negative) was essentially the same between the different laboratories.

Conclusion: With a few exceptions, all methods used routinely in the participating laboratories showed comparable performance, which assures the quality of diagnosis, despite the multiplicity of the methods.

Keywords: Mycoplasma bovis, Bovine respiratory disease, Real-time PCR, End-point PCR, Culture, Ring trial, Bronchoalveolar lavage fluid

\footnotetext{
* Correspondence: henk.wisselink@wur.nl

${ }^{1}$ Wageningen Bioveterinary Research, P.O. Box 65, 8200 AB Lelystad, The

Netherlands

Full list of author information is available at the end of the article
}

(c) The Author(s). 2019 Open Access This article is distributed under the terms of the Creative Commons Attribution 4.0 International License (http://creativecommons.org/licenses/by/4.0/), which permits unrestricted use, distribution, and reproduction in any medium, provided you give appropriate credit to the original author(s) and the source, provide a link to the Creative Commons license, and indicate if changes were made. The Creative Commons Public Domain Dedication waiver (http://creativecommons.org/publicdomain/zero/1.0/) applies to the data made available in this article, unless otherwise stated. 


\section{Background}

Bovine mycoplasmoses due to Mycoplasma (M.) bovis occur in the majority of countries in the world and infections are associated with a variety of clinical manifestations [1], of which respiratory diseases in calves are the most important in Europe [2]. M. bovis is considered to be one of the major emerging pathogens of cattle in industrialized countries threatening livestock production [3] and accounting for significant economic and production losses in the beef and dairy industries [2, 4].

In the absence of effective vaccines $[5,6]$, the control of M. bovis mycoplasmoses relies on good husbandry practices, early diagnosis and efficient antimicrobial treatments [2]. Co-infections with viruses and easy-to-culture bacteria which includes the Pasteurellaceae family and which are frequent in bovine respiratory diseases (BRD) [7], may complicate the diagnosis. Furthermore, asymptomatic animals may act as reservoirs, enhancing the disease persistence and spread within herds without clinical manifestations $[4,8]$. Hence, diagnostic tools for the detection of $M$. bovis need to be rapid, sensitive and specific.

Awareness of the importance of M. bovis in BRD has increased in the past decades although its prevalence might have been underestimated due to the lack of veterinary laboratories routinely monitoring for mycoplasmas. Serological methods, which indicates invasive infection [2] are best used as a herd-level disease diagnostic test, and are not ideal for disease investigations at the animal level as misdiagnosis may occur due to the lag period required for antibody formation or, in contrast, to the high seroprevalence in some cattle populations [9].

For direct diagnosis, conventional microbial culture of $M$. bovis is laborious and time-consuming (up to 7 days) as the bacterium has specific and demanding growth conditions. Furthermore, with limited options for specific selection for $M$. bovis by cultural means, diagnosis typically requires a post-culture identification test as other proven pathogenic or opportunistic mycoplasmas like $M$. dispar or M. bovirhinis and M. arginini, respectively can be isolated from the same clinical samples [10]. Traditional biochemical or growth inhibition tests used for species confirmation has been replaced by several identification techniques such as sandwich ELISA [11], dot immunobinding membrane-filtration tests (MF-dot) [12] or more recently matrix-assisted laser desorption ionization-time of flight mass spectrometry (MALDITOF MS) $[13,14]$ that demonstrate high specificity, but do not improve the overall sensitivity of the diagnosis since they depend on a cultivation step to isolate the organism.

Hence, PCR-based techniques that allow rapid (i.e. within a few hours), sensitive and specific detection have contributed significantly to an improved diagnosis of $M$. bovis. Today several highly sensitive and species-specific PCRs targeting a variety of genes are used in the diagnosis of Mycoplasma-associated diseases for M. bovis in cattle herds with BRD and/or mastitis (see review by Parker et al., [15] and Table 1 for an overview). However, few studies are dedicated to the comparison of overall performance of these assays [16]. This study describes the comparison of several PCR methods currently used in six national veterinary institutes across Europe. Three different sample panels were collated and used to assess the analytical specificity, analytical sensitivity and comparability of the different PCR methods, respectively. Results were also compared, when appropriate, to those obtained through culturing. The sensitivity and comparability panels were based on bronchoalveolar fluids (BALFs), artificially contaminated or naturally infected, and hence the comparison of the different methods included the whole workflow from DNA extraction to PCR analysis.

\section{Materials \\ Mycoplasma isolates, growth conditions and viability controls}

The mycoplasma isolates used in the study are listed in Table 2. Isolates were grown in PPLO broth, modified as previously described [17], at $37^{\circ} \mathrm{C}$ in $5 \% \mathrm{CO}_{2}$, except for $M$. dispar and $U$. diversum which were grown in modified Friis medium and Eatons general purpose growth medium, respectively [18]. The length of culture was adapted for each species from 3 to 5 days to reach early stationary phase. To enumerate the $M$. bovis culture used for the analytical sensitivity assay (see hereafter), the number of colony forming units (CFU) per ml was determined by plating spots of $2 \mu \mathrm{l}$ of serial 10 fold broth dilutions onto PPLO agar plates. After incubation for 5 days, colonies from nonconfluent spots were counted under a stereomicroscope and the mean final cell concentration was determined.

For viability control of $M$. bovis in the BALF samples, laboratories (Lab) 1 and 4 performed a bacteriological examination for $M$. bovis using different methods. In Lab 1, PPLO agar plates were flooded with $200 \mu \mathrm{l}$ of each BALF (dilution series for sensitivity and individual BALF for comparability), the excess of culture was removed by pipetting and after 5 days incubation the colonies were observed under a stereomicroscope. If colonies of typical mycoplasma morphology were observed, they were picked and grown in PPLO broth until turbidity was observed. In parallel direct 10 fold dilution series up to $10^{-5}$ of BALF in PPLO were prepared and incubated until turbidity. Turbid broths (from picked colonies or dilution series) were analysed for the presence of $M$. bovis or other mycoplasma species using MF-dot tests [12] and/or real time PCR (MPBO50). In Lab 4, 
Table 1 Overview of PCR methods in literature for detection of M. bovis

\begin{tabular}{|c|c|c|c|}
\hline Method & Characteristics & Targeted gene & Published by \\
\hline \multirow[t]{4}{*}{ End-point PCR } & For detection of M. bovis in milk samples and nasal swabs & oppD/F & [36] \\
\hline & For detection of M. bovis and M. agalactiae in diagnostic samples & uvrC & [26] \\
\hline & $\begin{array}{l}\text { Design of a species-specific PCR assay for the identification and differentiation of } \\
\text { M. agalactiae and M. bovis }\end{array}$ & polc & [25] \\
\hline & Development of a M. bovis species-specific PCR assay. & Vsp & [37] \\
\hline PCR-DGGE & $\begin{array}{l}\text { PCR followed by denaturing gradient gel electrophoresis (DGGE) fingerprinting. } \\
\text { For the simultaneous detection of mixed mycoplasma populations including } \\
\text { M. bovis. }\end{array}$ & $16 \mathrm{~S}$ rRNA & {$[27,35,38]$} \\
\hline DNA microarray & For parallel detection of 37 Mycoplasma species, including M. bovis. & $23 \mathrm{~S}$ rRNA; tuf & [39] \\
\hline \multirow[t]{6}{*}{ Real-time PCR } & For quantifying the load of M. bovis in milk, nasal and conjunctival samples from cattle. & oppD & [23] \\
\hline & For pathogens associated with BRD, including M. bovis. & oppD & [40] \\
\hline & For detection of $M$. bovis in diagnostic samples. & uvrC & {$[24,41,42]$} \\
\hline & For detection of $M$. bovis in bovine milk samples & fusA & [43] \\
\hline & For detection of $M$. bovis in bovine milk and lung samples. & $16 \mathrm{~S}$ rRNA & [44] \\
\hline & $\begin{array}{l}\text { For detection of M. bovis, M. dispar and M. bovirhinis in bronchoalveolar lavage fluid } \\
\text { from calves. }\end{array}$ & $16 \mathrm{~S}$ rRNA & [22] \\
\hline
\end{tabular}

BALF samples were cultured directly on Friis medium plates and also one 10 fold dilution was made from the BALF in Friis broth [19]. Plates were incubated for 7 days at $37^{\circ} \mathrm{C}$ in $5 \% \mathrm{CO}_{2}$, and inspected every second day under the microscope for mycoplasma growth. Broth medium was incubated at $37^{\circ} \mathrm{C}$ for 3 days. The growth and color change were monitored every other day. All broth cultures were examined for presence of $M$. bovis by oppD real-time PCR and suspected samples were subcultured on Friis medium plates as described above. The results of the $o p p D$ real-time PCR on broth were compared with the results of this PCR assay directly on BALF samples and if there was an increase of $\mathrm{Ct}$ values it was concluded that this increase was due to

Table 2 Identity of 17 Mycoplasma strains used in the ring trial to test for the analytical specificity of M. bovis PCR methods

\begin{tabular}{|c|c|c|c|c|c|}
\hline Strain & Number & Strain collection & Source & Country & Origin (sample, year) \\
\hline Mycoplasma bovis & F8065 & Anses & [45] & France & Bovine respiratory disease, 2014 \\
\hline Mycoplasma bovis & F8127 & Anses & [45] & France & Bovine respiratory disease, 2013 \\
\hline Mycoplasma bovis & F8428 & Anses & {$[45]$} & France & Bovine respiratory disease, 2013 \\
\hline Mycoplasma bovis & F8619 & Anses & [45] & France & Bovine respiratory disease, 2014 \\
\hline Mycoplasma bovis & L11480 & Anses & [45] & France & Bovine respiratory disease, 2000 \\
\hline Mycoplasma bovis & L15711 & Anses & [45] & France & Bovine respiratory disease, 2011 \\
\hline Mycoplasma bovis & L8905 & Anses & {$[45]$} & France & Bovine respiratory disease, 1995 \\
\hline Acholeplasma laidlawii & $\begin{array}{l}\text { PG8 NCTC } 10116 \\
\text { or ATCC } 23206\end{array}$ & Anses & TS & UK & Sewage, 1936 \\
\hline Mycoplasma agalactiae & 5632 & Anses & [46] & Spain & Caprine, joint, 1991 \\
\hline Mycoplasma alkalescens & $\begin{array}{l}\text { PG51 NCTC } 10135 \\
\text { or ATCC } 29103\end{array}$ & Anses & TS & UK & Bovine nasal cavity \\
\hline Mycoplasma arginini & F9238 & Anses & Field strain (unpublished) & France & Respiratory disease, caprine, 2014 \\
\hline Mycoplasma bovigenitalium & $\begin{array}{l}\text { PG11 NCTC } 10122 \\
\text { or ATCC } 19852\end{array}$ & Anses & TS & Not known & Bovine genital tract \\
\hline Mycoplasma bovirhinis & F11020 & Anses & Field strain (unpublished) & France & Bovine respiratory disease, 2016 \\
\hline Mycoplasma canadense & $275 C$ & Anses & TS & Canada & Prepuce of a bull \\
\hline Mycoplasma canis & $\begin{array}{l}\text { PG14- NCTC } 10146 \\
\text { or ATCC } 19525\end{array}$ & Anses & TS & UK & Dog throat \\
\hline Mycoplasma dispar & NCTC 10125 & APHA & TS & UK & Pneumonic calf lung \\
\hline Ureaplasma diversum & $382 \mathrm{~B} 16$ & APHA & Field strain (unpublished) & UK & Bovine, swab from unspecified site \\
\hline
\end{tabular}


multiplication of viable $M$. bovis organisms. A BALF was considered as culture positive when at least one of the different methods returned a positive result.

\section{Sample panels}

Three different sample panels (I, II and III) were compiled to assess the analytical specificity, analytical sensitivity and comparability of the different $M$. bovis PCR methods, respectively (see hereafter for details of the sample panels).

\section{Sample panel I: Analytical specificity on DNAs of mycoplasma strains}

The analytical specificity was defined as the ability of the assay to distinguish target from non-target organisms [20]. The inclusion list comprises seven M. bovis isolates belonging to different subtypes that used to circulate or are currently circulating in France and other countries [21], while the exclusion list was composed of ten strains belonging to ten non-target mycoplasma species that can be recovered from BRD clinical samples (9/10) or are genetically close to $M$. bovis (1/10, M. agalactiae) (Table 2). For each strain, a $20 \mathrm{ml}$ broth culture was grown at $37^{\circ} \mathrm{C}$ up to the stationary phase and mycoplasma cells were harvested by a $30 \mathrm{~min}$ centrifugation at $9000 \mathrm{~g}$ and $4{ }^{\circ} \mathrm{C}$. DNA was extracted from pelleted cells either using 3 DNeasy Mini Spin Columns from the DNeasy 96 Blood \& Tissue Kit (Qiagen) or the Maxwell ${ }^{\circ}$ 16 Tissue DNA purification kit (Promega). Each DNA solution was diluted to a $10 \mathrm{ng} / \mu \mathrm{l}$ concentration, aliquoted into anonymized individual tubes (marked from A to Q) for each laboratory and frozen at $-80^{\circ} \mathrm{C}$.

\section{Sample panel II: Analytical sensitivity on BALF spiked with M. bovis}

The analytical sensitivity of the $M$. bovis PCR assays was defined as the ability of the assay to detect the lowest concentration of $M$. bovis in CFU/ml in BALF [20]. A pool of BALFs sampled from specific pathogen free (SPF) calves of 3 weeks old was spiked using an enumerated culture of strain 147,826-1 (VB) (isolated in South of Sweden in 2016 from mastitis milk) in order to get a final $1 \times 10^{8} \mathrm{CFU} / \mathrm{ml}$ concentration. Ten-fold serial dilutions $(n=7)$ of this mixture were prepared in BALF resulting in a range from $1 \times 10^{7}$ to $1 \times 10^{1} \mathrm{M}$. bovis $\mathrm{CFU} / \mathrm{ml}$. All dilutions were performed in the same BALF pool, aliquoted afterwards in separate anonymized samples (marked from 1 to 7 ) for every laboratory and frozen at $-80^{\circ} \mathrm{C}$.

\section{Sample panel III: Comparability on BALF samples from the field}

For comparison of the results of the PCR methods on field samples, BALF samples $(n=21)$ were selected from a set of BALF from veal calves, sampled between October 2013 and April 2014 and used for the evaluation of a triplex real-time PCR for the detection of $M$. bovis, M. dispar and M. bovirhinis in BALF [22] and stored since then at $-80^{\circ} \mathrm{C}$. In that study, BALF samples were tested from calves on farms with BRD and were positive for $M$. bovis with $\mathrm{Ct}$ values below 30 (in this work BALFs $n^{\circ} 4,6,8,9,13,16$ and 20), weak-positive with $\mathrm{Ct}$ values between 30 and 40 (in this work BALFs n - $1,3,14,15,18,19$ and 21) or negative with $\mathrm{Ct}$ values above 40 (in this work BALFs $n^{\circ} 2,5,7,10,11,12,17$ ). These 21 BALFs were anonymised, aliquoted and sent to each participating laboratory on dry ice. Two laboratories performed bacteriological examination of the BALF samples as described above.

\section{Participating institutes}

Six institutes for Animal Health in six different European countries participated in the $M$. bovis PCR ring trial: the Animal and Plant Health Agency (APHA), UK; the National Veterinary Institute, Technical University of Denmark (DTU), Denmark; the Finnish Food Safety Authority (Evira), Finland; the French Agency for Food, Environmental and Occupational Health \& Safety (ANSES), France; the National Veterinary Institute (SVA), Sweden and the Wageningen Bioveterinary Research (WBVR), The Netherlands. The institutes were anonymously listed as laboratories 1 to 6 .

\section{Distribution of samples and ring trial procedures}

Samples were randomised and sent anonymized on dry ice to all participating laboratories, which were asked to i) note the date of reception, ii) confirm that samples were still frozen at reception and iii) store the samples at $-80{ }^{\circ} \mathrm{C}$ until analysis. A report form was prepared and every laboratory was asked to report results in terms of positive, negative or doubtful for $M$. bovis or, in case of problems with the validation of negative and positive controls, as a run failure. Users of end-point PCR were asked to report the electrophoresis technique used and the quantity of PCR mix loaded. Users of quantitative tests were asked to report the $\mathrm{Ct}$ values and also the $\mathrm{Ct}$ value of the internal positive control (IPC) of the test. All laboratories were asked to document the platform on which the PCR method was run.

For analysis of samples of panel I, every laboratory was asked to i) defrost the aliquots at room temperature (not longer than $30 \mathrm{~min}$ ), ii) make a $1 / 10$ dilution of each DNA sample (to be stored at $4{ }^{\circ} \mathrm{C}$ before running PCR test), iii) run a PCR on the original DNA sample and on the 1/10 DNA dilutions in duplicate using $5 \mu$ of each DNA sample in the PCR mix. All these analyses had to be performed on the day when samples were defrosted and in the same run. 
For analysis of samples of panel II and III every laboratory was asked to i) extract DNA from $200 \mu \mathrm{l}$ BALF of the entire dilution series of spiked samples (panel II) and from the field samples (panel III) using the method routinely performed in their laboratory, ii) resuspend the DNA in an equal $200 \mu \mathrm{l}$ volume, iii) use $5 \mu \mathrm{l}$ of the DNA in their PCR mix and iv) run the PCR test in duplicate.

\section{Methods used in the laboratory}

Five different DNA extraction methods were used by the laboratories participating in the ring trial (Table 3). Labs 1,3 and 4 used the same technique (spin column, silica-membrane extraction from Qiagen). The other three laboratories (2, 5 and 6) all used a robot with magnetic-particle technology. However the kits and the type of robots varied (Table 3 ).

Seven different PCR methods were used by the participating laboratories (Table 3). Labs 1, 2 and 4 used the commercial real-time MPBO50 kit from ThermoFisher Scientific which is based on the polC gene. Labs 3, 4 and 5 used PCRs based on the detection of the oppD gene [23]. However the chemistry and / or real-time PCR kits differed (Table 3). Lab 4 used a real-time PCR based on detection of the $u v r C$ gene [24] and Lab 6 used a real-time PCR based on the V3-V4 16S rRNA gene [22]. For amplification, six different real-time PCR platforms were used (LightCycler 480, Stratagene MX3000, Rotor-Gene, Bio-Rad CFX96, ABI 7500 and ABI 7500 Fast).

In addition to real-time PCRs, end-point PCRs $(n=2)$ were also run. Lab 1 used a PCR method based on polC [25] whereas Lab 2 used $u v r C$ [26] for detection of $M$. bovis and a PCR-DGGE method based on the $16 \mathrm{~S}$ rRNA gene [27], without primary culture step.

\section{Statistical analysis}

The linear correlation coefficient $(r)$, the slope and the amplification efficiency (E) of the PCR methods were calculated between the $\mathrm{Ct}$ values obtained in the real-time PCRs and the number of $M$. bovis CFU/ml [28]. Calculations were performed using Microsoft Excel spreadsheets.

\section{Results}

\section{Analytical specificity using DNAs of mycoplasma strains} (sample panel I)

The analytical specificity of the PCR methods was evaluated using DNAs of a panel of target and non-target Mycoplasma isolates (sample panel I; $n=$ 17). All real-time PCR tests were positive using $M$. bovis DNA extracts except for one test, which was obviously due to an experimental failure (from lab 3) (Fig. 1). Negative PCR results were obtained with the non- $M$. bovis DNAs, except for the $16 \mathrm{~S}$ PCR by lab 6 which showed a clear positive result on $M$. agalactiae
(Fig. 1). Furthermore, several real-time PCR tests of DNA samples from which $M$. bovis was expected to be absent showed weak positive results with $\mathrm{Ct}$ values greater than or equal to 37 (Fig. 1). This was especially valid for samples with $50 \mathrm{ng}$ of DNA in the PCR mix, i.e. $5 \mu \mathrm{l}$ of $10 \mathrm{ng} / \mu \mathrm{l}$ solution. Hence, with most of the PCR assays, $\mathrm{Ct} \geq 37$ were further regarded as doubtful.

Results from end-point PCRs were in agreement with those of real-time PCRs except for the uvrC PCR using $1 / 10$ diluted DNA of $M$. bovis that was poorly reproducible giving alternatively positive or negative results (Fig. 1). The PCR-DGGE analysis fully confirmed the identification of the DNA samples.

\section{Analytical sensitivity on BALF spiked with $M$. bovis (sample panel II)}

The analytical sensitivity of the $M$. bovis PCR methods was determined on ten-fold serial dilutions of a pool of BALFs from SPF calves, spiked with M. bovis (Sample panel II; Fig. 2). A high linear correlation $(r>0.97)$ between the $\mathrm{Ct}$ values and the number of $\mathrm{CFU} / \mathrm{ml}$ was found for all assays. The slopes ranged from -2.5 (Lab 1) to -3.4 (Lab 5) which corresponds to an efficiency (E) of 166 and 97\% respectively (Fig. 2).

The limit of detection (LOD) expressed in CFU/ml in the BALF pool varied from 10 to $10^{3}$ between the different real-time PCR assays. This variation was observed even between laboratories using the same PCR kit (MPBO50, used in Lab 1, 2 and 4) and the same DNA extraction kit (Qiagen, silica-membrane, Lab 1 and 4), suggesting an impact of the PCR platform (LightCycler 480 in Lab 1 versus Bio-rad CFX96 in Lab 4). Similarly, in the PCR method based on the $o p p D$ gene the LOD was $10^{2}$ (Labs $3 \& 4$ ) and $10^{3}$ $\mathrm{CFU} / \mathrm{ml}$ (Lab 5) using different types of DNA extraction methods (Labs 3 \&4: spin column; Lab 5: magnetic-particle technology). Detection based on the $16 \mathrm{~S}$ rRNA gene resulted in a low LOD due to the duplicate copies of the target in the genome (Lab 6). In Lab 4, three different techniques were used on the same extracted DNA batches which allows a classification of the real-time PCR methods as a function of their respective sensitivity, i.e. $u v r C>o p p D>$ polC.

The LOD of the end-point PCRs was comparable to that of real-time PCR when targeting the polC gene $\left(10^{2}\right.$ $\mathrm{CFU} / \mathrm{ml}$, Lab1) but was higher when targeting the $u v r C$ gene $\left(10^{6} \mathrm{CFU} / \mathrm{ml}, \mathrm{Lab} 2\right)$ or performing the PCR-DGGE method $\left(10^{5} \mathrm{CFU} / \mathrm{ml}, \mathrm{Lab} 2\right)$.

The culture methods used for viability control of $M$. bovis in the BALF samples seemed to be very sensitive since for both laboratories (Lab 1 \& Lab 4) the LOD was $10^{2} \mathrm{CFU} / \mathrm{ml}$ of BALF. 


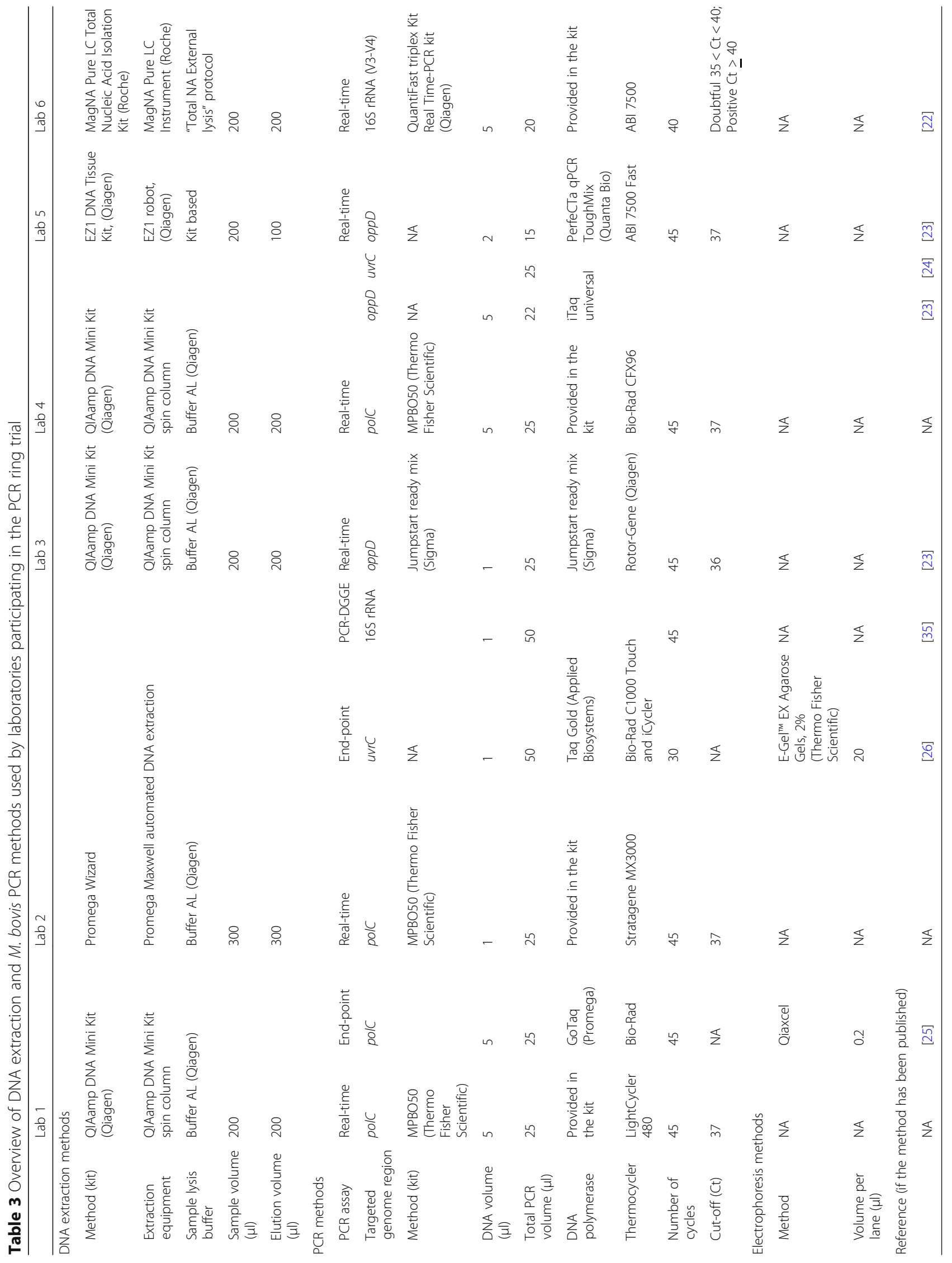




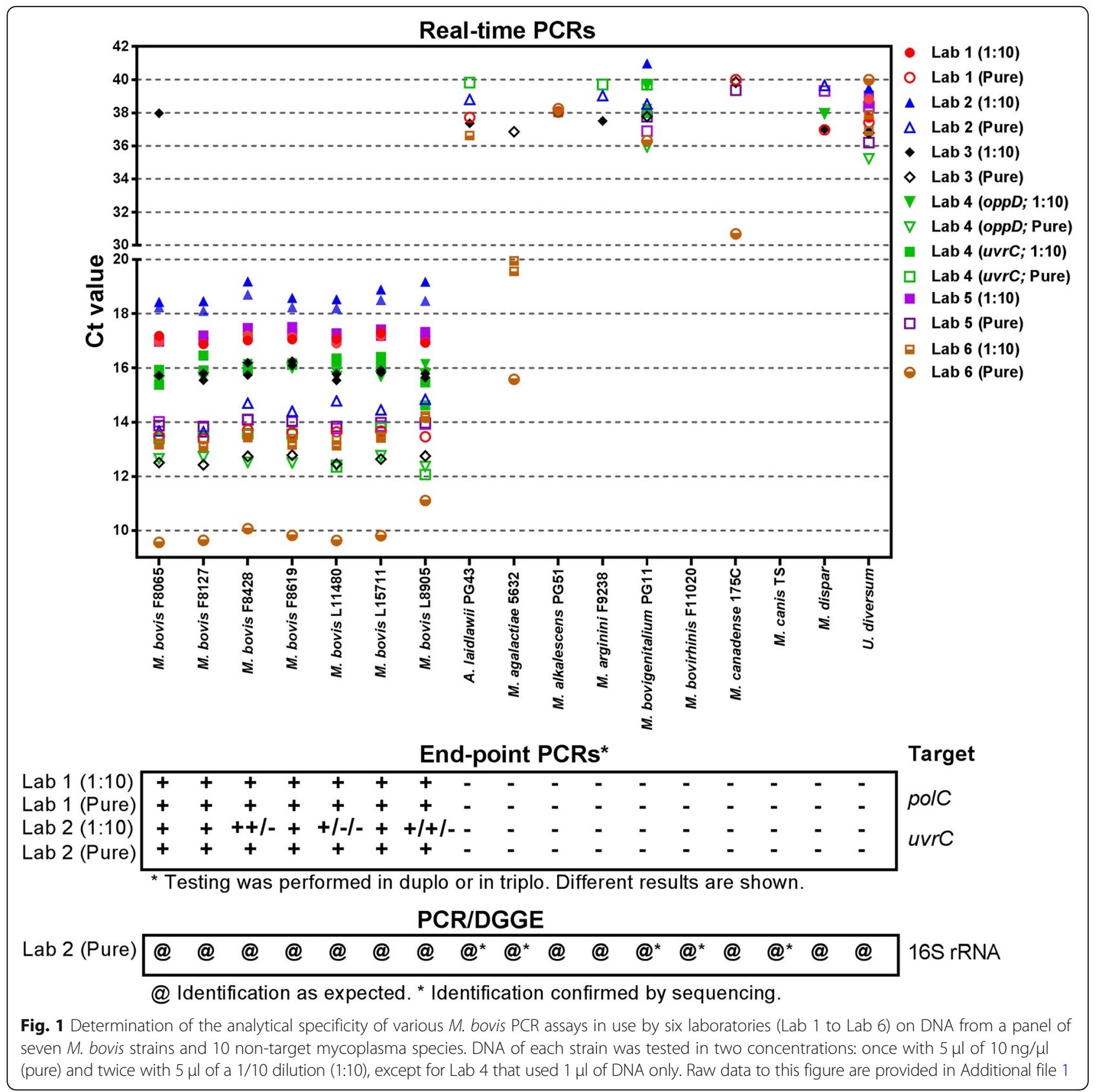

\section{Comparability on BALF samples from the field (sample panel III)}

A set of 21 BALFs from calves originating from herds with BRD were analysed by PCR in the six laboratories and by culture methods in Lab 1 and 4 . Figure 3 shows the mean $\mathrm{Ct}$ values (two repeats) obtained by each laboratory. For each BALF, the median dispersion of the mean $\mathrm{Ct}$ values was 3.5 but differences reached up to 6.6 $\mathrm{Ct}$ values at the maximum. For instance, BALF $\mathrm{n}^{\circ} 1$ had a mean $\mathrm{Ct}$ value of 37.1 in the hands of Lab 1 but 30.5 in the hands of Lab 6 (Fig. 3).
Of the seven BALF samples considered as negative (by culture but also by considering previous results from Cornelissen et al. [22], i.e. BALFs $n^{\circ}$ 2, 5, 7, 10, 11, 12, 17; Fig. 3), none were detected with a $\mathrm{Ct}<37$. In contrast, of the 14 BALFs that were culture-positive, 11 (79\%) were detected by all laboratories with $\mathrm{Ct}<37$, whereas three $\left(\mathrm{n}^{\circ} 14,15\right.$ and 21; Fig. 3) were weak-positive, doubtful $(\mathrm{Ct}=37)$ or negative at the different laboratories (Fig. 3).

The polC-end point PCR gave coherent results compared to the real-time PCR assays in $86 \%(12 / 14)$ culture-positive BALFs but failed to detect BALF $\mathrm{n}^{\circ} 15$ 


\section{Real-time PCRs}
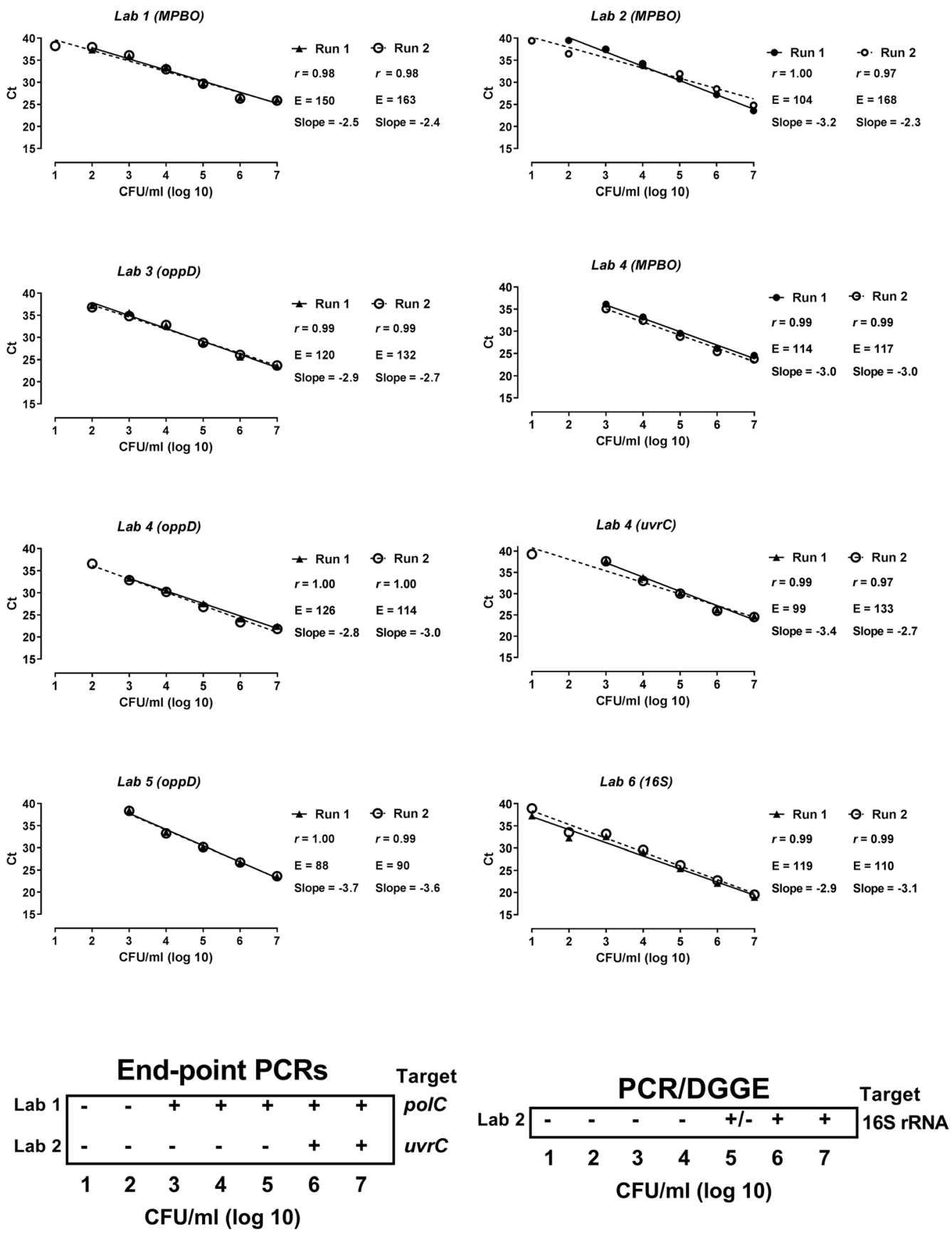

M. bovis culture

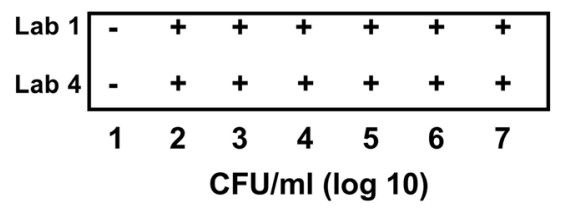

Fig. 2 (See legend on next page.) 
(See figure on previous page.)

Fig. 2 Determination of the analytical sensitivity of various M. bovis PCR assays in use by six laboratories (Lab 1 to Lab 6) on spiked bronchoalveolar lavage fluid (BALF) samples. Ten-fold serial dilutions $(n=7)$ of a mixture of $1 \times 10^{8} \mathrm{M}$. bovis CFU/ml were prepared in BALF resulting in a range of $1 \times$ $10^{7}$ to $1 \times 10^{1} \mathrm{M}$. bovis CFU/ml and tested by the various PCR methods. Viability of $\mathrm{M}$. bovis in the BALF samples was verified with culture. Raw data to this figure are provided in Additional file 1

and 21. In contrast, the $u v r C$ end-point PCR and the PCR-DGGE analysis yielded 64\% (9/14) and 50\% (7/14) false negative results, although the latter test was able to identify also $M$. dispar and $M$. bovirhinis DNA from these samples.

\section{Discussion}

Six laboratories participated in the ring trial and a total of five different DNA extraction methods, seven different real-time and/or end-point PCR methods targeting four different genes and six different real-time PCR platforms were used (Table 2). Among the tested PCR assays there was one ready-to-use commercial kit (MPBO kit, ThermoFisher Scientific); the others were in-house, validated, PCR assays.

Differences in analytical specificity and analytical sensitivity were observed between the various real-time PCR methods. A clear cross reaction was observed in the real-time PCR method of Lab 6 with M. agalactiae, which is genetically close to $M$. bovis with a $99 \%$ nucleotide similarity between their $16 \mathrm{~S}$ rRNA sequences [29] but usually not isolated from the bovine host with a few
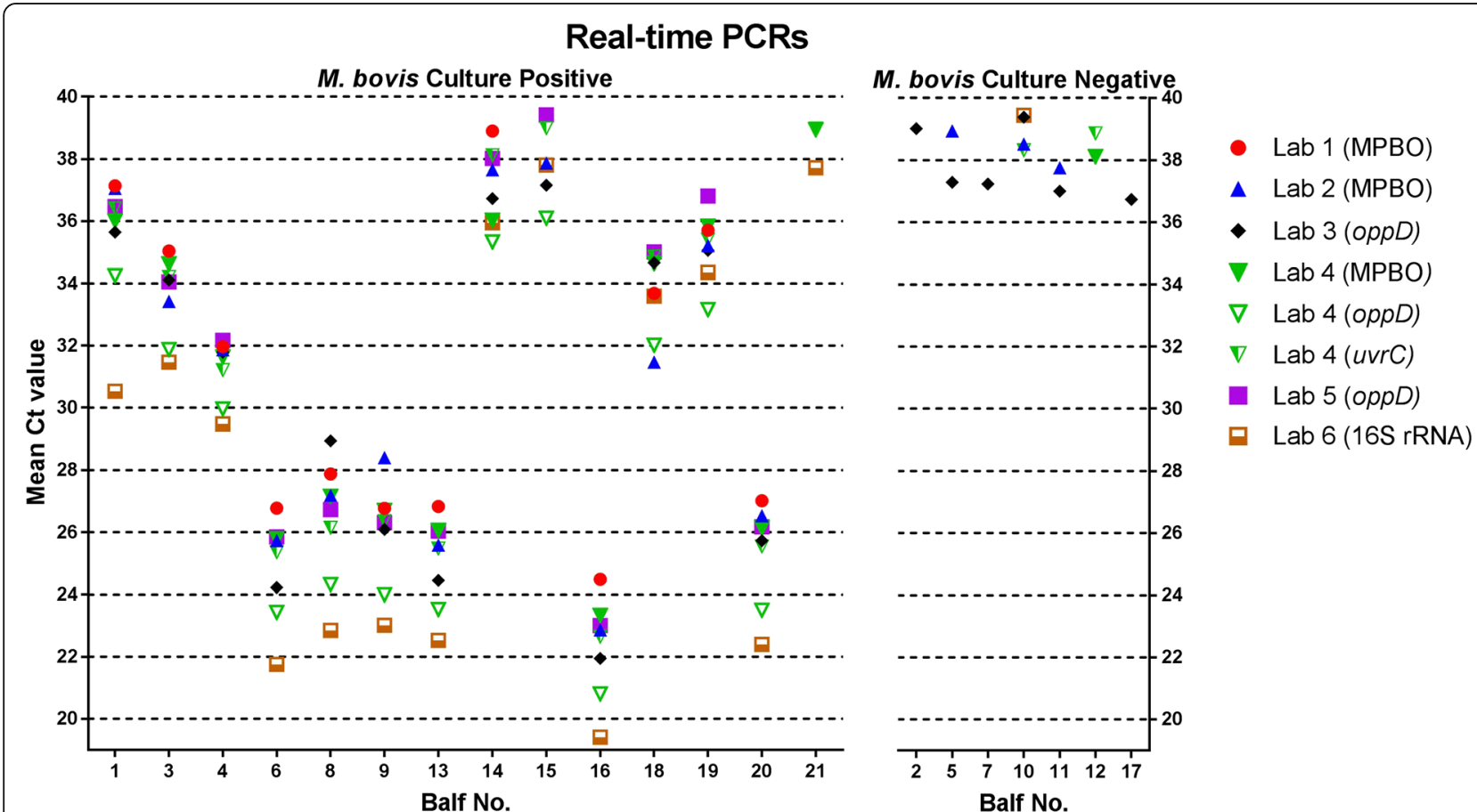

End-point PCRs*

M. bovis Culture Positive
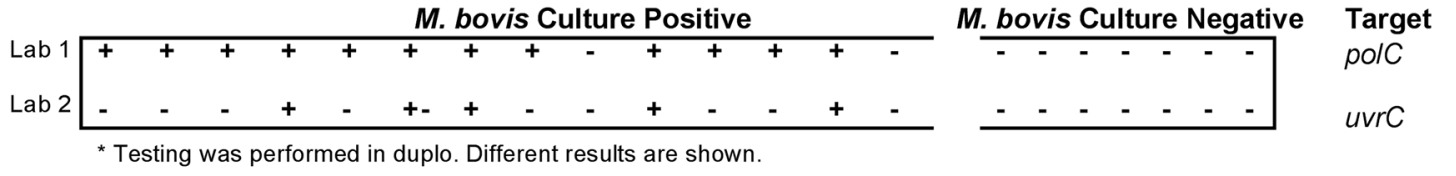

\section{PCR/DGGE}

M. bovis Culture Positive

M. bovis Culture Negative

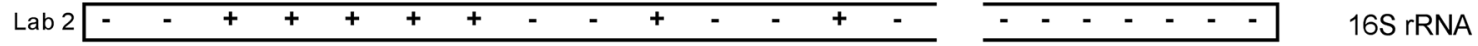

Fig. 3 Comparability of results of various PCR methods in use by six laboratories (Lab 1 to Lab 6) on bronchoalveolar lavage fluid (BALF) samples $(n=21)$ from veal calves from farms with bovine respiratory disease (BRD). BALF samples were tested twice by the PCR methods and the mean Ct values were calculated from the real-time PCRs. Viability of M. bovis in the BALF samples was verified with culture. On the basis of the culture results, the figure was split in two parts, either with BALF samples negative or positive for $M$. bovis by culture. Raw data to this figure are provided in Additional file 1 
exceptions [30]. Moreover, weak positive results with $\mathrm{Ct}$ values between 37 and 40 were obtained on non-target Mycoplasma strains which could result in misinterpretation of results and highlights the requirement for thorough assessment of cut-off during validation at individual laboratory level. Differences in the analytical sensitivity appeared to be 10-100 fold between the different real-time PCR methods. Furthermore, in the comparability assay differences in mean $\mathrm{Ct}$ values between laboratories appeared to be $6.6 \mathrm{Ct}$ values at the maximum, the median was $3.5 \mathrm{Ct}$ values. A difference of $3.3 \mathrm{Ct}$ values is equal to a 10 fold difference and differences between the real-time PCR methods were therefore 10 to 100 fold, which is comparable to the difference in analytical sensitivity. Nevertheless, this difference did not impact on the qualification of the BALF samples (i.e. positive versus negative), with a few exceptions (Fig. 3). Apparently different real-time PCR methods with a varying sensitivity can be used for the diagnosis of $M$. bovis in clinical BALF samples.

For the present ring trial, BALF from veal calves was selected as a representative clinical sample to compare the efficiency of PCR diagnosis of $M$. bovis. It is estimated that $M$. bovis is a contributing factor in at least $25 \%$ of cases of BRD in calves and that BALFs are valuable samples for detection of $M$. bovis in cases of BRD in calves [2, 3, 21, 31]. Other possible samples from BRD cases could include lung tissue samples or swabs from the respiratory tract. However, these would have been less suitable than BALF for homogenous aliquoting and distribution to participating laboratories. Our results should not be generalized to other types of samples, like semen, or milk, or joint fluid/swabs that are increasingly being used for the diagnosis of $M$. bovis [1, 4, 32]. Ring trials based on these types of sample materials warrant further investigation.

The variety of methods in this study is consistent with the number of PCRs described in literature for $M$. bovis detection (Table 1). In order to take into account the specific know-how of each participating laboratory, no technique was imposed upon the laboratories in the design of our ring trial. This is because the focus of the study was to compare the various tests as normally used as evaluated by each laboratory for routine testing. The main consequence of this choice was that the statistical analysis performed in this study was essentially descriptive, with more detailed statistical analysis of the results considered beyond the scope of the present study. While, differences in protocols (such as the number of amplification cycles, the volume of DNA in the mix, etc.) may in part explain the differences in overall performances of the methods, it was not the aim of the paper to analyse these in detail.
In the present ring trial, the detection of $M$. bovis by culture from naturally or artificially contaminated BALFs, as conducted by two laboratories, showed a sensitivity comparable or even better than that of real-time PCR assays. This is in agreement with a previous study that showed no significant difference in the proportion of culture and PCR positive samples [33]. However the authors also stated that the best method to detect and identify $M$. bovis was also dependent on the sample type. Here, the naturally infected BALFs contained several other bacteria [34] including mycoplasmas [22] among which $M$. bovirhinis, which is a known fast grower. Hence, $M$. bovirhinis present in the sample could overgrow $M$. bovis and lead to false negative results depending on the techniques used afterwards to differentiate $M$. bovis from M. bovirhinis. The choice of the most acceptable culture medium is also critical and hence diagnosis by culture needs far more expertise than is required to perform PCR, although the latter necessitates good quality DNA and a reliable PCR assay. Of the PCR-based tests investigated in this study only the triplex real-time PCR used by Lab 6 and the PCR-DGGE method used by Lab 2 are able to offer simultaneous identification of three [22] or more Mycoplasma species, including hardly cultivable or non-cultivable ones from clinical samples [35]. It should also be noted that PCR-DGGE is most routinely applied in the diagnostic laboratory setting following an initial culture step for clinical sample diagnostics which was not performed here. In the end, the choice of the most suitable method for M. bovis diagnosis must reflect the veterinary requirements for a robust and reproducible approach to testing.

\section{Conclusion}

In this study the performance of PCR methods in use by six Animal Health laboratories across six European countries was compared in a ring trial. The analytical specificity of the PCR methods was comparable except for $M$. agalactiae, which was tested positive by Lab 6 because of the use of $16 \mathrm{~S}$ rRNA as the target gene. The LOD of the real-time PCR methods varied from 10 to $10^{3} \mathrm{CFU} / \mathrm{ml}$ and differences in sensitivity to the same order of magnitude were found in the real-time PCR assays on BALF samples of naturally infected veal calves. Despite these differences, and with the exception of the end-point PCR on the $u v r C$ gene and the PCR-DGGE method, highly comparable PCR results were obtained on BALF samples from naturally infected veal calves leading to the conclusion that several DNA isolation and PCR methods can give consistent diagnostic test results. Culture results confirmed the presence of viable $M$. bovis in the tested BALF samples, and also confirmed the diagnostic test results of the M. bovis PCR methods on these samples. 


\section{Additional file}

Additional file 1: Raw data to Figs. 1, 2 and 3 are provided in Additional file 1. (XLSX 29 kb)

\section{Abbreviations}

BALF: Bronchoalveolar lavage fluid; BRD: Bovine respiratory disease; $\mathrm{Ct}$ value: Threshold cycle; E: Efficiency; Lab: Laboratory; LOD: Limit of detection; NA: Not applicable; PCR/DGGE: PCR with denaturing gradient gel electrophoresis fingerprinting; $r$ : Correlation coefficient; TS: Type strain

\section{Acknowledgements}

The authors thank Agnès Tricot (ANSES), Tomas Jinnerot (SVA), Herma BuysBergen (WBVR) and Marianne Vahl (WBVR) for running the PCR assays.

\section{Funding}

This study was funded by the CoVetLab project "Towards better Mycoplasma bovis control by improving early diagnosis, isolate typing and susceptibility profiles" (www.covetlab.org).

\section{Availability of data and materials}

All datasets supporting our findings are available from the corresponding author on reasonable request.

\section{Authors' contributions}

HJW, AR, AA, TP, HL and FT designed and HJW, BS, AR and FT organized the ring trial. JP, AMA, AA, NV, JH and AC acquired the data and HJW and FT analysed the data. HJW and FT drafted the manuscript. All authors read and approved the final manuscript.

\section{Ethics approval and consent to participate}

Sampling of the calves was granted an exemption from requiring ethics approval by the institutional Animal Experiment Commission "Dier Experimenten Commissie (DEC) Lelystad (2013111.b), because sampling was performed for diagnostic purposes. Verbal informed consent was obtained from the farmers for use of BALF.

\section{Consent for publication}

Not applicable.

\section{Competing interests}

The authors declare that they have no competing interests.

\section{Publisher's Note}

Springer Nature remains neutral with regard to jurisdictional claims in published maps and institutional affiliations.

\section{Author details}

${ }^{1}$ Wageningen Bioveterinary Research, P.O. Box 65, 8200 AB Lelystad, The Netherlands. ${ }^{2}$ Animal and Plant Health Agency (APHA), Surrey, UK. ${ }^{3}$ National Veterinary Institute (SVA), Uppsala, Sweden. ${ }^{4}$ Finnish Food Safety Authority Evira, Kuopio, Finland. ${ }^{5}$ National Veterinary Institute, Technical University of Denmark, Lyngby, Denmark. ${ }^{6}$ Anses, Lyon Laboratory, JRU Ruminants Mycoplasmoses, Anses, VetAgro Sup, University of Lyon, Lyon, France.

Received: 3 July 2018 Accepted: 25 February 2019

Published online: 12 March 2019

References

1. Burki S, Frey J, Pilo P. Virulence, persistence and dissemination of Mycoplasma bovis. Vet Microbiol. 2015;179:15-22.

2. Nicholas RA, Ayling RD. Mycoplasma bovis: disease, diagnosis, and control. Res Vet Sci. 2003:74:105-12.

3. Nicholas RA. Bovine mycoplasmosis: silent and deadly. Vet Rec. 2011;168: 459-62.

4. Maunsell FP, Woolums AR, Francoz D, Rosenbusch RF, Step DL, Wilson DJ, Janzen ED. Mycoplasma bovis infections in cattle. J Vet Intern Med. 2011;25: $772-83$
5. Mulongo M, Prysliak T, Perez-Casal J. Vaccination of feedlot cattle with extracts and membrane fractions from two Mycoplasma bovis isolates results in strong humoral immune responses but does not protect against an experimental challenge. Vaccine. 2013;31:1406-12.

6. Soehnlen MK, Aydin A, Lengerich EJ, Houser BA, Fenton GD, Lysczek HR, Burns CM, Byler LI, Hattel AL, Wolfgang DR, Jayarao BM. Blinded, controlled field trial of two commercially available Mycoplasma bovis bacterin vaccines in veal calves. Vaccine. 2011;29:5347-54.

7. Griffin D, Chengappa MM, Kuszak J, McVey DS. Bacterial pathogens of the bovine respiratory disease complex. Vet Clin North Am Food Anim Pract. 2010:26:381-94.

8. Aebi M, van den Borne BH, Raemy A, Steiner A, Pilo P, Bodmer M. Mycoplasma bovis infections in Swiss dairy cattle: a clinical investigation. Acta Vet Scand. 2015;57:10

9. Calcutt MJ, Lysnyansky I, Sachse K, Fox LK, Nicholas RAJ, Ayling RD. Gap analysis of Mycoplasma bovis disease, diagnosis and control: an aid to identify future development requirements. Transbound Emerg Dis. 2018; 65(Suppl. 1):91-109.

10. Ayling RD, Gosney F, Hlusek M. Mycoplasma diagnostics, some results, and what we still don't know about Mycoplasma bovis disease. Cattle Pract. 2015;23:248-51.

11. Ball HJ, Finlay D. Diagnostic application of monoclonal antibody (MAb)based sandwich ELISAs. In: Miles R, Nicholas R, editors. Mycoplasma protocols. Totowa: Humana Press; 1998. p. 127-32.

12. Poumarat $F$, Perrin $B$, Longchambon $D$. Identification of ruminant mycoplasmas by dot immunobinding on membrane filtration (MF dot). Vet Microbiol. 1991;29:329-38.

13. Pereyre S, Tardy F, Renaudin H, Cauvin E, Del Pra Netto Machado L, Tricot A Benoit F, Treilles M, Bebear C. Identification and subtyping of clinically relevant human and ruminant mycoplasmas by use of matrix-assisted laser desorption ionization-time of flight mass spectrometry. J Clin Microbiol. 2013:51:3314-23.

14. Randall LP, Lemma F, Koylass M, Rogers J, Ayling RD, Worth D, Klita M, Steventon A, Line K, Wragg P, Muchowski J, Kostrzewa M, Whatmore AM. Evaluation of MALDI-ToF as a method for the identification of bacteria in the veterinary diagnostic laboratory. Res Vet Sci. 2015;101:42-9.

15. Parker AM, Sheehy PA, Hazelton MS, Bosward KL, House JK. A review of mycoplasma diagnostics in cattle. J Vet Intern Med. 2018:32:1241-52.

16. Bashiruddin JB, Frey J, Konigsson MH, Johansson KE, Hotzel H, Diller R, de Santis P, Botelho A, Ayling RD, Nicholas RA, Thiaucourt F, Sachse K. Evaluation of PCR systems for the identification and differentiation of Mycoplasma agalactiae and Mycoplasma bovis: a collaborative trial. Vet J. 2005;169:268-75.

17. Poumarat F, Longchambon D, Martel $\mathrm{J}$. Application of dot immunobinding on membrane filtration (MF dot) to the study of relationships within " $M$. mycoides cluster" and within "glucose and arginine-negative cluster" of ruminant mycoplasmas. Vet Microbiol. 1992;32:375-90.

18. Nicholas RAJ, Baker SE. Recovery of mycoplasmas from animals. Methods Mol Biol. 1998;104:37-43.

19. Bölske G. Survey of mycoplasma infections in cell cultures and a comparison of detection methods. Zentralbl Bakteriol Mikrobiol Hyg A. 1988:269:331-40.

20. Saah AJ, Hoover DR. "Sensitivity" and "specificity" reconsidered: the meaning of these terms in analytical and diagnostic settings. Ann Intern Med. 1997; 126:91-4.

21. Becker CA, Thibault FM, Arcangioli MA, Tardy F. Loss of diversity within Mycoplasma bovis isolates collected in France from bovines with respiratory diseases over the last 35 years. Infect Genet Evol. 2015:33:118-26.

22. Cornelissen JB, de Bree FM, van der Wal FJ, Kooi EA, Koene MG, Bossers A, Smid B, Antonis AF, Wisselink HJ. Mycoplasma detection by triplex real-time PCR in bronchoalveolar lavage fluid from bovine respiratory disease complex cases. BMC Vet Res. 2017;13:97.

23. Sachse K, Salam HS, Diller R, Schubert E, Hoffmann B, Hotzel H. Use of a novel real-time PCR technique to monitor and quantitate Mycoplasma bovis infection in cattle herds with mastitis and respiratory disease. Vet J. 2010; 186:299-303.

24. Rossetti BC, Frey J, Pilo P. Direct detection of Mycoplasma bovis in milk and tissue samples by real-time PCR. Mol Cell Probes. 2010;24:321-3.

25. Marenda MS, Sagne E, Poumarat F, Citti C. Suppression subtractive hybridization as a basis to assess Mycoplasma agalactiae and Mycoplasma bovis genomic diversity and species-specific sequences. Microbiology. 2005: 151:475-89. 
26. Subramaniam S, Bergonier D, Poumarat F, Capaul S, Schlatter Y, Nicolet J, Frey J. Species identification of Mycoplasma bovis and Mycoplasma agalactiae based on the uvrC genes by PCR. Mol Cell Probes. 1998;12:161-9.

27. McAuliffe L, Ellis RJ, Ayling RD, Nicholas RA. Differentiation of Mycoplasma species by 165 ribosomal DNA PCR and denaturing gradient gel electrophoresis fingerprinting. J Clin Microbiol. 2003;41:4844-7.

28. Raymaekers M, Smets R, Maes B, Cartuyvels R. Checklist for optimization and validation of real-time PCR assays. J Clin Lab Anal. 2009;23:145-51.

29. Pettersson B, Uhlen M, Johansson KE. Phylogeny of some mycoplasmas from ruminants based on 16S rRNA sequences and definition of a new cluster within the hominis group. Int J Syst Bacteriol. 1996;46:1093-8.

30. Catania S, Gobbo F, Schiavon E, Nicholas RAJ. Severe otitis and pneumonia in adult cattle with mixed infection of Mycoplasma bovis and Mycoplasma agalactiae. Vet Rec Case Rep. 2016;4:art. no. e000366.

31. Doyle D, Credille B, Lehenbauer TW, Berghaus R, Aly SS, Champagne J, Blanchard P, Crossley B, Berghaus L, Cochran S, Woolums A. Agreement among 4 sampling methods to identify respiratory pathogens in dairy calves with acute bovine respiratory disease. J Vet Intern Med. 2017;31:954-9.

32. Haapala V, Pohjanvirta T, Vahanikkila N, Halkilahti J, Simonen H, Pelkonen S, Soveri T, Simojoki H, Autio T. Semen as a source of Mycoplasma bovis mastitis in dairy herds. Vet Microbiol. 2018;216:60-6.

33. Parker AM, House JK, Hazelton MS, Bosward KL, Sheehy PA. Comparison of culture and a multiplex probe PCR for identifying Mycoplasma species in bovine milk, semen and swab samples. PLoS One. 2017;12:e0173422.

34. Wisselink HJ, Cornelissen J, van der Wal FJ, Kooi EA, Koene MG, Bossers A, Smid $B$, de Bree FM, Antonis AFG. Evaluation of a multiplex real-time PCR for detection of four bacterial agents commonly associated with bovine respiratory disease in bronchoalveolar lavage fluid. BMC Vet Res. 2017;13:221.

35. McAuliffe L, Ellis RJ, Lawes JR, Ayling RD, Nicholas RA. 16S rDNA PCR and denaturing gradient gel electrophoresis; a single generic test for detecting and differentiating Mycoplasma species. J Med Microbiol. 2005;54:731-9.

36. Hotzel H, Heller M, Sachse K. Enhancement of Mycoplasma bovis detection in milk samples by antigen capture prior to PCR. Mol Cell Probes. 1999;13: $175-8$.

37. Tenk M, Balint A, Stipkovits L, Biro J, Dencso L. Detection of Mycoplasma bovis with an improved pcr assay. Acta Vet Hung. 2006;54:427-35.

38. Tardy F, Gaurivaud P, Tricot A, Maigre L, Poumarat F. Epidemiological surveillance of mycoplasmas belonging to the 'Mycoplasma mycoides' cluster: is DGGE fingerprinting of $16 \mathrm{~S}$ rRNA genes suitable? Lett Appl Microbiol. 2009:48:210-7.

39. Schnee C, Schulsse S, Hotzel H, Ayling RD, Nicholas RA, Schubert E, Heller M, Ehricht R, Sachse K. A novel rapid DNA microarray assay enables identification of 37 mycoplasma species and highlights multiple mycoplasma infections. PLoS One. 2012;7:e33237.

40. Kishimoto M, Tsuchiaka S, Rahpaya SS, Hasebe A, Otsu K, Sugimura S, Kobayashi S, Komatsu N, Nagai M, Omatsu T, Naoi Y, Sano K, OkazakiTerashima S, Oba M, Katayama Y, Sato R, Asai T, Mizutani T. Development of a one-run real-time PCR detection system for pathogens associated with bovine respiratory disease complex. J Vet Med Sci. 2017;79:517-23.

41. Clothier KA, Jordan DM, Thompson CJ, Kinyon JM, Frana TS, Strait EL. Mycoplasma bovis real-time polymerase chain reaction assay validation and diagnostic performance. J Vet Diagn Investig. 2010;22:956-60.

42. Behera S, Rana R, Gupta PK, Kumar D, Sonal, Rekha V, Arun TR, Jena D. Development of real-time PCR assay for the detection of Mycoplasma bovis. Trop Anim Health Prod. 2018;50:875-82.

43. Boonyayatra S, Fox LK, Besser TE, Sawant A, Gay JM, Raviv Z. A PCR assay and PCR-restriction fragment length polymorphism combination identifying the 3 primary Mycoplasma species causing mastitis. J Dairy Sci. 2012;95:196-205.

44. Cai HY, Bell-Rogers P, Parker L, Prescott JF. Development of a real-time PCR for detection of Mycoplasma bovis in bovine milk and lung samples. J Vet Diagn Investig. 2005:17:537-45.

45. Khalil D, Becker CAM, Tardy F. Monitoring the decrease in susceptibility to ribosomal RNAs targeting antimicrobials and its molecular basis in clinical Mycoplasma bovis isolates over time. Microb Drug Resist. 2017;23:799-811.

46. Marenda MS, Vilei EM, Poumarat F, Frey J, Berthelot X. Validation of the suppressive subtractive hybridization method in Mycoplasma agalactiae species by the comparison of a field strain with the type strain PG2. Vet Res. 2004:35:199-212.

\section{Ready to submit your research? Choose BMC and benefit from:}

- fast, convenient online submission

- thorough peer review by experienced researchers in your field

- rapid publication on acceptance

- support for research data, including large and complex data types

- gold Open Access which fosters wider collaboration and increased citations

- maximum visibility for your research: over $100 \mathrm{M}$ website views per year

At BMC, research is always in progress.

Learn more biomedcentral.com/submissions 